\title{
Plant Based Anti-cancerous Superfoods, Boosting Immunity: A Coherent Critique
}

\author{
Tripti Verma* and Alka Gupta \\ Department of Food Nut and Public Health, Ethelind College of Home Science, \\ Sam Higginbottom University of Agriculture, Technology and Sciences, \\ Prayagraj, Uttar Pradesh, India \\ *Corresponding author
}

\section{Keywords}

Superfood, Cultured dairy product, Antineoplastic, Chemotherapeutic, Anti-cancerous

\section{Article Info}

Accepted:

15 April 2020

Available Online:

10 May 2020

\section{A B S T R A C T}

Introduction- Superfood is a nutritional term and a marketing tool for selling specific foods, dietary supplements, foods with selected food additives, promising an enhancement to health with supposed health benefits as a result of some part of its nutritional analysis, or its overall nutrient density. Objective of the study is to systematically critique the supplementation of superfoods and types of superfoods on the course of fighting against cancer and boosting immunity. Electronic search of Medline, Pub Med, Health Internetwork access to Review Initiative was conducted. Scientific evidence highlights on the fact that high intake of cancer-fighting foods like vegetables, fruit, calcium-rich foods and fiber was associated with a decreased risk of colorectal, lung and breast cancers, while red and processed meat intake, alcohol intake, combined with restricting intake of saturated and trans fats and added sugars, and maintenance of a body mass index $(\mathrm{BMI}<25)$ and abdominal obesity were associated with an increased risk of cancer. Promising potential naturally occurring super foods such as berries, green leafy vegetables, cruciferous vegetables, organic spices and hurbs, citrus fruits, Cultured dairy product, Traditional teas, mushrooms, Healthy unrefined fats and oils containing therapeutic properties to boost immunity and fighting against cancer. There is a need for the search of such natural-based anticancer therapies, explores the antineoplastic potential of these chemotherapeutic cancer superfoods and highlights the metabolic and molecular targets of these potential anti-cancer superfoods.

\section{Introduction}

Cardiovascular diseases the most renounce cause of death after that cancer is the second leading cause in most affluent countries. The 13.3 million new cases of cancer in 2010 were predicted to cost US\$290 billion, but the total costs were expected to increases to US\$ 458 billion in the year 2030 on basis of World Economic Forum in 2011 and it is believed that superfood do more than simply provide nutrients because they help to maintaining health and thereby reducing the risk of disease (1-3). According to Global cancer statistics 2018, it was estimated that around 2.25 million number of people living with the 
disease in India. Every year, Over 11,57,294 lakh new cancer patients has registered in India. Total number of 7,84,821 lakh cancer related patient goes to death due to the Cancer. Risk of developing cancer before the age of 75 years of male is $9.81 \%$ and in female is $9.42 \%$ (4).

Superfood is a nutritional term for food with supposed health benefits as a result of some part of its nutritional analysis, or its overall nutrient density. Superfood becomes a marketing term that is known as ultra-healthy, nutrient-packed, plant-based foods and dietary supplements. The foods or beverages or any other food ingredients that are essentially advised as having exceptional powers, essentially for fighting common health conditions, helping with everything from weight loss to energy, vitality, hormonal balance, anti aging. "Superfood" products were sold at a higher price than similar foods not marketed with the label.

\section{Super charge with the superfoods}

Many cancer survivors have been fortunate by using a combination of natural cancer treatments themselves at home, this duel approach can help support the entire body and mind in the healing process that can sometimes be long and very painful (5-6). Today, the early combination of chemotherapy and nutrition therapy is able to save the lives of cancer patients.

Studies suggest that 30 percent to 40 percent of all kinds of cancer can be prevented with a healthy lifestyle and dietary measures! And other sources claim that this number is in fact much higher, with around 75 percent of cancer cases being lifestyle-related. Eating a healing diet, vegetable juicing, consuming probiotic, taking immune-boosting supplements, busting stress and practicing healing prayer can make more empowered and hopeful when fighting against a disease, which goes a very long way in the healing process. The basic causes of cancer are complex and multifaceted, with possible causes including poor diet, exposure to environmental toxins, genetics, viruses or infections, high stress levels, poor digestion and nutrient absorption, faulty food habits, excess alcohol consumption and lack of physical activity. While most people choose to turn to conventional cancer treatments like chemotherapy, radiation or other drugs, there's also mounting evidence that cancer risk can be considerably reduced by following a healthy diet filled with anti-inflammatory foods like antioxidant, phytochemicals that could help in controlling other factors that kick off heightened oxidative stress, also called an "immune cataract"

The World Cancer Research Fund and the American Institute for Cancer Research suggest that most cancer is preventable, through a combination of smoking/tobacco avoidance, appropriate diet, regular physical activity and maintaining a healthy body weight. We know there is a strong link between diet and cancer, although it is very complex (7-8). Expert consensus suggests 9$40 \%$ of cancers are directly linked to diet and this risk is even greater if you are obese. Eating a healthy balanced diet that is high in fiber, fruit and vegetables, calcium-rich foods decreased risk of colorectal, lung and breast cancers, while red and processed meat intake, alcohol intake, unhealthy body mass index (BMI), and abdominal obesity were associated with an increased risk.

According to Wolfe (2009) reviewed that superfoods include foods that have a dozen or more unique properties and constitute a specific set of foodstuffs, natural or medium processed with numerous nutrients. They are food that according to studies they are able to increase vitality of the human body and can 
be a good choice for improving the overall health by strengthening the immune system.

\section{Eating only "superfood" arrest cancer?}

World Health Organization has suggested that the cancer can be reduced and controlled by implementing evidence-based strategies for cancer prevention, early detection of cancer and patient management. The therapeutic modalities available currently worldwide are surgery in combination with or without radiotherapy or chemotherapy. One of the preventive anticancer measures used all over are natural medicine or plant-based herbal formulations or pure phytochemicals. Scientific evidence highlights on the fact that reduction in risk of chronic disease like cancer is associated with intake of a diet that includes mostly of plant-based foods such as vegetables, fruits, whole grains, and legumes combined with restricting intake of saturated and trans fats and added sugars, and maintenance of a body mass index $(\mathrm{BMI}<25)$.

\section{Promising potential naturally occurring} super foods to boost immunity and fighting against cancer

By tracking extra nutrients and understanding the mechanism of action within the human body, scientist found interested to explore and promote more and more scientific research findings in different food ingredients (8-11). In particular, the most important superfoods according to the data obtained from several studies are the following;

\section{Nuts and seeds}

Chia seeds and flaxseeds are two of the most nutrient-dense seeds in the world. They provide fiber, omega-3 fatty acids and a range of important minerals. Hemp seeds, sesame seeds, pumpkin seeds and sunflower seeds are also beneficial and full of healthy fatty acids, as are walnuts, brazil nuts and almonds. Their health benefits and are best sprouted and can be used easily in smoothies, baked goods and with yogurt.

\section{Green leafy vegetables}

Leafy greens are the cornerstone of any healthy diet since they are exceptionally rich in vitamins, minerals, antioxidants and enzymes, yet very low in calories, fats, sodium and other toxins. Green leafy vegetables such as spinach, drumstick, fenugreeek, Kachnar, Poi leaves Lehsua and Kulfa saag are rich in antioxidants and micronutrient known to protect cancer, including vitamin $\mathrm{C}$ and beta-carotene. A 2017 study published in the Asian Pacific Journal of Cancer Prevention found the extract from moringa leaves acts as an as anticancer agent that reduces cancer cell growth and promotes cell death in several cancers. The Health benefits of Green leafy vegetables have shown in Table 1.

\section{Cruciferous vegetables}

Cruciferous vegetables are known to be powerful cancer killers and some of the best vitamin $\mathrm{C}$ foods widely available. Many are rich in glutathione, known as the body's "master antioxidant" as it has high freeradical-scavenging abilities. cruciferous vegetables like brussels sprouts, cabbage, cauliflower and turnips are nutrient-dense sources of a family of phytochemicals called isothiocyanates that are linked to cancer prevention, broccoli also contain sulforaphanes and indoles Nutrient content found in cabbage may have cancer-protective properties, especially against lung and esophageal cancer (12-14).

\section{Berries}

The Oxygen radical absorbance capacity (ORAC) scores of nearly all berries are very high, making them some of the top high- 
antioxidant foods in the world. Blueberries, raspberries, cherries, strawberries, goji berries, grapes, pomegranate and blackberries are easy to find and use in numerous types of recipes which is good news considering they supply vitamin $\mathrm{C}$, vitamin $\mathrm{A}$ and gallic acid, a powerful antifungal and antiviral agent that has beneficial effects of berries or their constituents including attenuation of inflammation, inhibition of angiogenesis, protection from DNA damage, as well as effects on apoptosis or proliferation rates of malignant cells, increases immunity. Blueberries are especially rich in proanthocyanidin antioxidants, which have been observed to have anti-aging properties in several animal studies and are capable of lowering free radical damage. The Nutritive value of Blue berries per $100 \mathrm{gm}$ fresh fruits are given in Table 2 .

\section{Brightly orange-colored fruits and vegetables (Citrus Fruits, Squash, Sweet Potatoes)}

Brightly colored pigments found in plant foods are a sure sign that they're beaming with phytochemicals, especially carotenoid antioxidants. This is exactly the reason you want to "eat the rainbow" and vary the colors of the foods on your plate. Carotenoids (alpha-carotene, beta-carotene, lycopene, lutein, cryptoxanthin) are derivatives of vitamin A found in many citrus fruits, sweet potatoes, berries, pumpkin, squashes and other plant foods. One of the most researched is beta-carotene, an essential nutrient for immune functioning; detoxification; liver health; and fighting cancers of the skin, eyes and organs (16-20).

\section{Fresh herbs and spices}

Turmeric, which contains the active ingredient curcumin, has been shown to decrease tumor size and fight colon and breast cancer Additionally, other herbs that act as immune system boosters include ginger, raw garlic, thyme, cayenne pepper, oregano, basil and parsley which can easily be used in many recipes, juices, dressings and smoothies. The antioxidant content of different Herbs and spices are described in Table 3.

Cinnamon is a widely consumed traditional herbal medicine that has diverse metabolic advantages such as ant-oncogenic activity.

The active vital component of turmeric, curcumin is a non-toxic compound well known for its inhibitory effect on the growth of cancer during the early period.

Basil leaves has been used as an antiinflammatory, immunomodulatory, antiinfective, anti-stress, antipyretic, antitussive, anti-diabetic, cardioprotective, neuroprotective and hepatoprotective agent

\section{Cultured dairy products}

Cultured dairy products are a rich source of "good bacteria" probiotics, which are microorganisms that promote a natural bacterial balance in your intestinal microflora and help increase immunity.

One of the easiest ways to consume more probiotics is in their most natural state, which includes raw milk products such as cheese, kefir and yogurt. Raw and cultured are key here, since fermentation produces probiotics but high heat processing used to pasteurize dairy can damage many of the vital nutrients, including the enzymes, proteins and probiotics. Most dairy today is loaded with hormones, antibiotics, pain killers and pesticide residue so buying organic is also important. Aim for six ounces of cultured dairy daily (probiotic yogurt, cottage cheese, goat milk kefir or amasai). 
Table.1 Health benefits of green leafy vegetables

\begin{tabular}{|c|c|}
\hline Green leafy vegetables & Health benefits \\
\hline Spinach & $\begin{array}{l}\text { It's also packed with folate, which plays a key role in red } \\
\text { blood cell production and the prevention of neural tube } \\
\text { defects in pregnancy. } 8\end{array}$ \\
\hline Drumstick & $\begin{array}{l}\text { The high levels of antioxidants (vitamins } \mathrm{C} \text { and } \mathrm{A} \text { ) found in } \\
\text { moringa leaves used to protect against cell damage, maintain } \\
\text { a healthy immune system, Moringa leaves also contain } \\
\text { essential amino acids that can boost the immune system. }\end{array}$ \\
\hline Fenugreek leaves & $\begin{array}{l}\text { It has wide spread uses in traditional Indian medicine for the } \\
\text { treatment of hypercholesterolemia and hypertriglyceridemia, } \\
\text { fenugreek seeds have received little attention as an agent in } \\
\text { the treatment of cancer. }\end{array}$ \\
\hline Kachnar & $\begin{array}{l}\text { It is used traditionally in dysentery, diarrhea, hemorrhoids, } \\
\text { piles, edema, laxative, anti-helmintic, astringent, anti- } \\
\text { leprotic, wound healing, anti-goitrogenic, anti-tumor, } \\
\text { antidote for snake poisoning, dyspepsia and carminative } \\
\text { disease. }\end{array}$ \\
\hline Poi leaves & $\begin{array}{l}\text { Fresh leaves, particularly of Basella rubra, are rich sources } \\
\text { of several vital carotenoid pigment anti-oxidants such as } \beta- \\
\text { carotene, lutein, zeaxanthin. }\end{array}$ \\
\hline Lehsua & $\begin{array}{l}\text { Lehsua is used in Ayurveda, and Unani system of medicine } \\
\text { for treating cold, cough, coryza, fever, and skin diseases. } \\
\text { Fruits of the tree are edible, slimy, and heavy to digest. They } \\
\text { are given in colic pain, disorders of blood, seminal weakness, } \\
\text { and sexual disorders. }\end{array}$ \\
\hline Kulfa saag & $\begin{array}{l}\text { Kulfa saag providing significant amounts of vitamins } \mathrm{A}, \mathrm{B} \\
\text { and } \mathrm{C} \text {. and decent amounts of protein, this leafy green } \\
\text { probably contains more Omega- } 3 \text { fatty acids than any other } \\
\text { commonly available vegetable source. }\end{array}$ \\
\hline
\end{tabular}


Table.2 Nutritive value of blueberries per $100 \mathrm{~g}$ fresh fruits

\begin{tabular}{|c|c|c|c|}
\hline \multicolumn{2}{|c|}{ Carbohydrates } & \multicolumn{2}{|l|}{ Vitamins } \\
\hline Fibers & $3.6 \mathrm{~g}$ & Vitamin A & $54.0 \mathrm{IU}$ \\
\hline Starch & $0,0 \mathrm{~g}$ & Niacin (Vit.B3) & $0.4 \mathrm{mg}$ \\
\hline Sugars & $14.7 \mathrm{~g}$ & Pantothenic acid (Vit B5) & $0,1 \mathrm{mg}$ \\
\hline Sucrose & $163 \mathrm{mg}$ & Vitamin B6 & $0,1 \mathrm{mg}$ \\
\hline Glucose & $7,222 \mathrm{mg}$ & Folate (Vit B9) & $6.0 \mathrm{mg}$ \\
\hline Fructose & $7,355 \mathrm{mg}$ & Vitamin C & $9,7 \mathrm{mg}$ \\
\hline \multicolumn{2}{|c|}{ Proteins (amino acids) } & Vitamin E ( $\alpha$-tocopherol) & $0,6 \mathrm{mg}$ \\
\hline Tryptophan & $3.0 \mathrm{mg}$ & $23.0 \mathrm{mg}$ & $19.3 \mathrm{mg}$ \\
\hline Threonine & $20.0 \mathrm{mg}$ & Choline & $6.0 \mathrm{mg}$ \\
\hline \multicolumn{2}{|c|}{ Isoleucine } & Betaine & $0.2 \mathrm{mg}$ \\
\hline Leucine & $44.0 \mathrm{mg}$ & \multicolumn{2}{|c|}{ Trace elements } \\
\hline Lysine & $13.0 \mathrm{mg}$ & Calcium & $6.0 \mathrm{mg}$ \\
\hline Methionine & $12.0 \mathrm{mg}$ & Iron & $0.3 \mathrm{mg}$ \\
\hline Cystine & $8.0 \mathrm{mg}$ & Magnesium & $6.0 \mathrm{mg}$ \\
\hline Phenylalanine & $26.0 \mathrm{mg}$ & Phosphorus & $12.0 \mathrm{mg}$ \\
\hline Tyrosine & $9.0 \mathrm{mg}$ & Potassium & $77.0 \mathrm{mg}$ \\
\hline Valine & $31.0 \mathrm{mg}$ & Sodium & $1.0 \mathrm{mg}$ \\
\hline Arginine & $37.0 \mathrm{mg}$ & Zinc & $0.2 \mathrm{mg}$ \\
\hline Histidine & $11.0 \mathrm{mg}$ & Copper & $0.1 \mathrm{mg}$ \\
\hline Alanine & $31.0 \mathrm{mg}$ & Manganese & $0.3 \mathrm{mg}$ \\
\hline Aspartic acid & $57.0 \mathrm{mg}$ & Fat and fatty acids & \\
\hline Glutamic acid & $91.0 \mathrm{mg}$ & Total fat & $0.3 \mathrm{~g}$ \\
\hline Glycine & $31.0 \mathrm{mg}$ & Total $\omega-3$ fatty acids & $58.0 \mathrm{mg}$ \\
\hline Proline & $28.0 \mathrm{mg}$ & Total $\omega-6$ fatty acids & $88.0 \mathrm{mg}$ \\
\hline
\end{tabular}


Table.3 Antioxidant content of different herbs and spices

\begin{tabular}{|c|c|c|c|c|}
\hline S.No. & $\begin{array}{c}\text { Herbs and } \\
\text { Spices }\end{array}$ & Scientific name & form & $\begin{array}{c}\text { Antioxidant } \\
\text { content } \\
\text { (mmol/100gm) }\end{array}$ \\
\hline 1. & Ajwain fruit pods & Trachyspermum ammi & Dried & 28.42 \\
\hline 2. & Basil & Ocimum sanctum & Dried & 30.87 \\
\hline 3. & Clove & Syzygium aromaticum & Whole, Dried & 252,6 \\
\hline 4. & Garlic & Allium sativum & Dried Ground & 2.21 \\
\hline 5. & Ginger & Zingiber officinale & Dried & 11.31 \\
\hline 6. & Oregano & Origanum vulgare & Dried & 44.99 \\
\hline 7. & Saunf & Foeniculum vulgare & Big, Dried & 7.09 \\
\hline 8. & Turmeric & Curcuma longa & Dried & 13.60 \\
\hline
\end{tabular}

Table.4 Polyphenols content found in Green tea

\begin{tabular}{|l|c|c|}
\hline Catechin in Green Tea Infusion & $\begin{array}{c}\text { Catechin } \\
\text { Concentration } \\
(\mathbf{m g} / \mathbf{L})^{*}\end{array}$ & $\begin{array}{c}\text { Catechin } \\
\text { Concentration } \\
(\mathbf{m g} / \mathbf{8} \text { fl oz) }\end{array}$ \\
\hline $\begin{array}{l}\text { Epigallocatechin-3-gallate } \\
\text { (EGCG) }\end{array}$ & $117-442$ & $25-106$ \\
\hline Epigallocatechin (EGC) & $203-471$ & $49-113$ \\
\hline Epicatechin-3-gallate (ECG) & $17-150$ & $4-36$ \\
\hline Epicatechin (EC) & $25-81$ & $6-19$ \\
\hline
\end{tabular}

*mg = milligram; $\mathrm{L}=$ liter; $\mathrm{fl} \mathrm{oz}=$ fluid ounce.

Cottage cheese, which is rich in sulfur protein and saturated fats, You can also increase your probiotic food intake without dairy by consuming cultured vegetables like kimchi, sauerkraut, coconut kefir, kombucha or natto.

\section{Healthy unrefined oils (Coconut, Flax, Cod Liver and Extra Virgin Olive Oil)}

The problem is that many of the conventional processed fats and oils widely consumed today are hydrogenated oils that are capable of destroying the membranes of our cells, leading to diseased cells and toxicity. Refined and rancid fats create problems throughout your entire body, leading to lower immune function, cell congestion and inflammation that kicks off disease. Replace refined vegetable oils, hydrogenated oils and Trans fats with quality oils, including flax oil, extra virgin olive oil, cod oil and coconut oil. These nourish your gut and promote better immune function, help you reach and maintain a healthy weight, plus flaxseed and cod liver oil contain essential omega- 3 fatty acids that can help energize your cells (21-24).

\section{Mushrooms}

Nutritious mushrooms vary in terms of their benefits, taste and appearance since hundreds of mushroom species are in existence today, but all are known to be immune-enhancers and many have been used to fight cancer for centuries. Reishi, cordyceps and maitake in particular can improve immune function and cell regeneration. 


\section{Traditional teas}

Metastasis is the most deadly aspect of cancer and results from several connected processes including cell proliferation, angiogenesis, cell adhesion, migration and invasion into the surrounding tissue. Several clinical and epidemiological studies have reported that the consumption of green tea can help decrease cancer risk. Green tea contains major polyphenolic compounds which have been shown to inhibit tumor invasion, angiogenesis and essential for tumor growth and metastasis. Black tea contains much lower concentrations of these catechins than green tea. The extended oxidation of black tea increases the concentrations of the arubigins and the aflavins, two types of complex polyphenols. Oolong tea contains a mixture of simple polyphenols, such as catechins, and complex polyphenols. The predominant polyphenols in green tea-EGCG, EGC, ECG, and EC are as follows in Table 4.

Hence concluded, in general, this paper discusses about cancer protective foods, especially the need for consuming appropriate diets with the change in cancer patients lifestyles and dietary patterns a great emphasis should be given on usage of plantderived natural compounds such as Curcumin, Paprika, Carotenoids, Lycopene, Sulforaphane, Polyphenols, Flavonids, Zeaxantins and Isocyanates, etc. Researchers have proved that superfood consumption can offer the human body an abundance of antimicrobial and antioxidant substances, fibers, plenty of vitamins $(A, B, C, K, E)$, micronutrient but also beneficial fatty acids such as $\omega-3, \omega-6$ and other ingredients in quantities that often exceed the typical daily intake of other foods. These compounds to be extremely promising agents for fighting cancer when incorporated in the diet as anticancer superfoods. Thus there is a need for the search of such natural-based anticancer therapies, explores the antineoplastic potential of these chemotherapeutic cancer superfoods and highlights the metabolic and molecular targets of these potential anti-cancer superfoods.

\section{References}

1. Ferlay J, Soerjomataram I, Ervik M, (2018). Global cancer statistics 2018: GLOBOCAN estimates of incidence and mortality worldwide for 36 cancers in 185 countries.

2. The science behind superfoods: are they really super, (2014), European Food Information Council.

3. Martyn Caplin, (2018). Diet and cancer: Can superfoods or dietary supplements help, $5^{\text {th }}$ European Nutrition and Dietetics Conference, June 16-18, 2016 Rome, Italy, journal of nutrition and food science.

4. Fitzgerald M (2014). "It's a Bird! It's a Plane! It's Superfood!" Diet Cults: The Surprising Fallacy at the Core of Nutrition Fads and a Guide to Healthy Eating for the Rest of US. Pegasus Books. ISBN 978-160598-560-2.

5. American Cancer Society. (2016). Available from: http://www. cancer.org.

6. Sanskruti Saka, Anshika Nikita Singh, Neeti Sharma, Potential Anti-Cancer Superfoods: A Minireview Symbiosis School of Biomedical Sciences, Symbiosis International University, Gram-Lavale; Taluka-Mulshi, Pune 412115,

7. Wolfe D. (2009), Superfoods: The food and medicine of the future. California: North Atlantic Books, 10-49.

8. Composition of Foods Raw (2013). USDA National Nutrient Database for Standard Reference.

9. Kanchan Lata Singh, D. K. Singh and Vinay Kumar Singh, Multidimensional Uses of Medicinal Plant Kachnar (Bauhinia variegata Linn.) Malacology Laboratory, Department of Zoology, DDU Gorakhpur University, Gorakhpur-273 009 UP, India

10. Asbestos. Com

11. Shabana Shabbeer, Michelle Sobolewski, Sushant Kachhap, Nancy Davidson, Michael A. Carducci, and Saeed Khan(2009). 
Fenugreek: a naturally occurring edible spice as an anticancer agent, Cancer Biol Ther. 8(3): 272-278.

12. Hecht SS (2000). Inhibition of carcinogenesis by isothiocyanates, Drug Metab Rev., 32(34):395-411.

13. Johnson IT (2002). Glucosinolates: bioavailability and importance to health. Int $\mathbf{J}$ Vitam Nutr Res., 72(1): 26-31.

14. AICR'S FOODS THAT FIGHT CANCER ${ }^{\mathrm{TM}}$ Broccoli \& Cruciferous Vegetables

15. Aleksandra S. Kristo, Dorothy Klimis-Zacas, and Angelos K. Sikalidis (2016). Protective Role of Dietary Berries in Cancer Antioxidants (Basel), 5(4): 37.

16. Lien Ai Pham-Huy, Hua He, and Chuong Pham-Huy (2008). Free Radicals, Antioxidants in Disease and Health, Int $\mathbf{J}$ Biomed Sci., 4(2): 89-96.

17. Furness D, Fenech M, Dekker G, Khong TY, Roberts C, Hague W. (2013). Folate, vitamin B12, vitamin B6 and homocysteine: impact on pregnancy outcome. Matern Child Nutr., 9(2): 155-66.

18. Benzie IFF, Wachtel-Galor S, (2011). Antioxidants in Herbs and Spices Herbal Medicine: Biomolecular and Clinical Aspects. 2nd edition.

19. Koppikar SJ, Chaudhari AS, Suryavanshi SA, Kumari S, Chattopadhyay S, Kaul Ghanekar R.(2010). Aqueous cinnamon extract (ACE-c) from the bark of Cinnamomum cassia causes apoptosis in human cervical cancer cell line (SiHa) through loss of mitochondrial membrane potential. BMC Cancer, 18: 10:210

20. Duvoix A, Blasius R, Delhalle $S$, Schnekenburger M, Morceau F, Henry E, (2005). Effect of curcumin on the interaction between androgen receptor and $\mathrm{Wnt} / \beta$ catenin in $\mathrm{LNCaP}$ xenografts. Chemopreventive and therapeutic effects of curcumin. Cancer Lett,
223:181-90.11

21. Hatcher H, Planalp R, Cho J, Torti FM, Torti SV. (2008). Curcumin: from ancient medicine to current clinical trials. Cell Mol Life Sci, 65:1631-52.

22. Bhat M, Zinjarde SS, Bhargava SY, Kumar AR, Joshi BN. (2008). Antidiabetic Indian Plants: a Good Source of Potent Amylase Inhibitors. Evid Based Complement Alternat Med.

23. Samy RP, Pushparaj PN, Gopalakrishnakone P. (2008). A compilation of bioactive compounds from Ayurveda. Bioinformation, 3:100-110.

24. Samson J, Sheeladevi R, Ravindran R. (2007) Oxidative stress in brain and antioxidant activity of Ocimum sanctum in noise exposure. Neurotoxicology, 28: 679685.

25. Mukhtar H, Ahmad N. (2000). Tea polyphenols: Prevention of cancer and optimizing health. American Journal of Clinical Nutrition, 71(6 Suppl): 1698S$1702 \mathrm{~S}$.

26. $\mathrm{Wu} \mathrm{AH}, \mathrm{Yu}$ MC. (2006) Tea, hormonerelated cancers and endogenous hormone levels. Molecular Nutrition and Food Research, 50(2):160-169.

27. Santana-Rios G, Orner GA, $\mathrm{Xu} \mathrm{M}$, Izquierdo-Pulido M, Dashwood RH. (2001). Inhibition by white tea of 2-amino-1-methyl6-phenylimidazo[4,5-b]pyridine-induced colonic aberrant crypts in the F344 rat. Nutrition and Cancer, 41(1 and 2):98-103.

28. Reto M, Figueira ME, Filipe HM, Almeida CM. (2007) Chemical composition of green tea (Camellia sinensis) infusions commercialized in Portugal. Plant Foods for Human Nutrition, 62(4):139-144.

\section{How to cite this article:}

Tripti Verma and Alka Gupta. 2020. Plant Based Anti-cancerous Superfoods, Boosting Immunity: A Coherent Critique. Int.J.Curr.Microbiol.App.Sci. 9(05): 1886-1894. doi: https://doi.org/10.20546/ijcmas.2020.905.214 